\title{
Rh-endostatin Concomitant with Chemotherapy Versus Single Agent Chemotherapy for Treating Soft Tissue and Bone Sarcomas: A Systematic Review and Meta-Analysis
}

\author{
Zhuo Ma\#, Lifang Guo ${ }^{\#}$, Xiangli Cui, He Liu, Lihong Liu \\ Pharmacy Department of Beijing Chao-Yang Hospital, Capital Medical University, Beijing 100020, P.R. China.
}

Received, July 20, 2018; Revised, September 15, 2018 Accepted, October 13, 2018; Published, October 17, 2018.

\begin{abstract}
Objectives: Rh-endostatin (recombinant human endostatin) approved by China State Food and Drug Administration (CFDA) for the treatment of non-small-cell lung carcinoma (NSCLC), is a potent endogenous inhibitor of angiogenesis. Recently, several studies have evaluated the efficacy of rh-endostatin combined with chemotherapy in the treatment of bone and soft tissue sarcomas. Here, we conducted a systematic review and meta-analysis to assess available evidence. Methods: Pubmed, Embase, Web of Sciences, the Cochrane Library and two Chinese literature databases (CNKI, WanFang) were systematically searched till May 20, 2018. Randomized controlled trials (RCTs) and cohort studies which compared the outcomes of Rh-endostatin combined with chemotherapy versus chemotherapy alone for treating bone sarcomas or soft tissue sarcomas were included. The primary outcome was overall survival rate (OSR). Secondary outcomes included objective remission rate (ORR), clinical benefit rate (CBR), disease control rate (DCR), distant metastasis rate (DMR) and adverse effects (AEs). The methodological quality of the included studies was evaluated. Data analysis was performed by Revman 5.3 software. Results: 9 studies comprising 839 patients were included. The pooled results indicated that, compared with chemotherapeutic agents alone, rh-endostatin combined group had a significant benefit in 1-year and 2-year OSR. However, there were no difference between 5-year OSR. ORR, CBR and DMR were higher in rh-endostatin combined group. No significant difference was observed for incidence of AEs. Conclusions: Rh-endostatin combined chemotherapeutic agents significantly improved clinical efficacy compared with chemotherapeutic agents alone in treating bone and soft tissue sarcomas. Moreover, combination of rh-endostatin with chemotherapy didn't increase incidence of AEs. But more high quality RCTs with large sample size should be done in the future to confirm the conclusion.
\end{abstract}

\section{INTRODUCTION}

Sarcomas, a heterogeneous group of rare tumors that arise from mesenchymal cells, develop in supporting or connective tissue such as the bone, muscle, nerves, blood vessels, and fatty tissue ${ }^{[1]}$. Sarcomas define a number of different names based on the tissue of origin. They account for approximately $1 \%$ of all adult malignancies and $15 \%$ of pediatric malignancies ${ }^{[2]}$. Sarcomas are usually divided into two categories: soft tissue and bone sarcomas. Soft tissue sarcomas that account for almost $20 \%$ of pediatric and $1 \%$ of adult malignancies, can affect any part of the body. According to the database of the Surveillance, Epidemiology, and End Results (SEER) Program, more than 13000 people will be diagnosed with soft tissue sarcomas each year in the United States ${ }^{[3]}$. Soft tissue sarcomas are grouped into several subtypes. Gstrointestinal stromal tumors (GISTs) (18\%), followed by unclassifed sarcomas (16\%), liposarcomas (15\%), leiomyosarcoma (12\%), synovial sarcoma $(10 \%)$ and malignant peripheral nerve sheath tumor $(6 \%)$ are the most common soft tissue sarcomas ${ }^{[1]}$. The two most common types of bone sarcomas are osteosarcoma and chondrosarcoma, making up $67 \%$ of all bone sarcoma diagnoses. Osteosarcoma is mostly diagnosed in children and teenagers. Patients with advanced osteosarcoma who have pulmonary metastases have a poor prognosis, with the OSR is low than $50 \%$. Since higher grade tumors are more likely to undergo metastasis, they are usually treated aggressively. Nowadays, the classic chemotherapies for sarcomas include oxorubicine, gemcitabine, cisplatin, dacarbazine, methotrexate and docetaxel et $\mathrm{al}^{[4-8]}$. Although chemotherapy plays a major role in the treatment of soft tissue and bone sarcomas, longterm treatments with high doses of cytotoxic drugs usually cause severe side effects ${ }^{[4,5]}$.

Corresponding Author: Zhuo Ma \& Lihong Liu, Pharmacy Department of Beijing Chao-Yang Hospital, Capital Medical University, No.8 Gongren Tiyuchang Nanlu, Chaoyang District, Beijing. E-mail: liulihong@bjcyh.com _ \#These authors contributed equally to this work 
Therefore, there is a need for new combination chemotherapies or other methods for the treatment of sarcomas. Considering that angiogenesis is a key factor for tumor growth and metastasis both in cancer and sarcomas, anti-angiogenic agents could be effective therapies for this disease.

Together with surgery, chemotherapy, and radiotherapy, anti-angiogenic agents have been widely recognised as the fourth modality in cancer treatment ${ }^{[9]}$. Endostatin, a C-terminal proteolytic fragment of collagen XVIII, is a potent endogenous tumor angiogenesis inhibitor with broad-spectrum antitumor activities ${ }^{[10]}$. Rh-endostatin, a novel recombinant human endostatin with an additional nine-amino acid sequence at the $\mathrm{N}$ terminus, was approved by China State Food and Drug Administration (CFDA) as for the treatment of NSCLC in 2005. It is widely used in China and showed outstanding clinical efficacy in clinic ${ }^{[11]}$. Recently, rh-endostatin combined with conventional cytotoxic therapy to treat malignant tumors has been extensively studied, and showed that combination therapy was more effective than chemotherapy alone therapy ${ }^{[12]}$. However, whether anti angiogenic therapy combined with chemotherapy really benefits patients with soft tissue and bone sarcomas was still unclear. The current study presents a systematic review to quantify the clinical benefits and toxicities of rh-endostatin concomitant with chemotherapy versus chemotherapy alone for treating soft tissue and bone sarcomas.

\section{METHODS}

\section{Literature search}

Published articles (until May 20, 2018) were systematically identified from Pubmed, Embase, the Web of Sciences, the Cochrane Library, and two Chinese literature databases (CNKI and WanFang). The following search terms were utilized: (()(((sarcomas) OR bone sarcomas) OR soft tissue sarcomas) OR osteosarcoma) OR chondrosarcoma)) AND (((rh-endostatin) OR endostatin) OR recombinant human endostatin injection). The search was conducted without language restrictions.

\section{Study selection}

Articles reporting the comparative outcomes of rhendostatin combined with chemotherapeutic agents versus chemotherapeutic agents alone for treating bone sarcomas or soft-tissue sarcomas were eligible for the meta-analysis, and the types of studies included were prospective studies, retrospective studies and RCTs. Studies matched with the following criteria were included: (1) studies must be designed to compare rh-endostatin plus conventional chemotherapy to conventional chemotherapy alone; (2) patients must be diagnosed with bone or soft tissue sarcomas; (3) outcome measures must be reported. Studies were excluded with the following criteria: (1) studying on animals not human; (2) studies lacking efficient control group; (3) articles for which the full text was not available.

Two reviewers (Z.M. and L.F.G.) independently searched the literature and examined the relevant studies for further assessment of data. Each reviewer was blinded to the other reviewer in the process of data extraction. Another author L.H.L .was consulted if there were any discrepancies.

\section{Data management and outcomes}

The following data were extracted from each study: the characteristics of each study (author, study design, publication year), patient population (numbers of patients, age, sources of tumor, grade), interventions, clinical outcomes (1-year, 2-year and 5-year OSR; ORR; CBR; DCR; DMR and AEs).

\section{Quality appraisal}

Two authors (Z.M. and L.F.G.) independently assessed risk of bias for each study. Included RCTs were assessed the risk of bias according to the Cochrane Collaboration's tool from Cochrane Handbook and observational studies were assessed by Newcastle-Ottawa Scale (NOS). Any disagreements were resolved by consultation with the third reviewer (L.H.L.).

\section{STATISTICAL ANALYSIS}

All statistical analyses were conducted in RevMan 5.3. Pooled odds ratios (ORs) and $95 \%$ confidence intervals (CIs) were calculated for categorical outcomes. Statistical heterogeneity among studies was assessed by $\chi^{2}$-based $\mathrm{Q}$ test $(p<0.10$ was defined to indicate significant heterogeneity). MantelHaenszel fixed effects model was used when there was no significant heterogeneity between studies; otherwise, a random effects model was used. In order to evaluate the stability of results without estimation bias from small sample study, sensitivity analysis was performed by exclusion of small sample study $(\mathrm{n}<100)$ one by one. Publication bias was evaluated using the funnel plot method.

\section{RESULTS}

\section{Literature search}

Our search resulted in 540 titles and abstracts. A total of 473 were excluded after review of the titles: 97 
were duplicate articles, 315 were not relevant and 61 were not clinical trials. 67 articles remained for fulltext analysis. Overall, 9 studies with 839 patients were considered to meet the inclusion criteria, and included in the meta-analysis ${ }^{[13-21]}$. The whole literature search process was summarized in Figure 1.

\section{Study description}

Characteristics of the eligible studies were presented in Table 1. This meta-analysis included three prospective cohort studies ${ }^{[13,14,16]}$, three retrospective cohort studies $^{[18-20]}$ and three $\mathrm{RCTs}^{[15,17,21]}$. The sample sizes ranged from 17 to 330 in the identified studies. All studies were conducted in China. Five studies enrolled patients with bone sarcomas only ${ }^{[13-}$ ${ }^{17]}$, and three studies enrolled patients with soft tissue sarcomas only ${ }^{[18,20,21]}$. While in one study patients diagnosed with bone and soft tissue sarcomas were included $^{[19]}$. Tumor stage of the patients ranged from phaseIIto phase IV.

\section{Quality of included studies}

Seven factors were used to evaluate the bias of included RCTs according to the Cochrane risk of bias tool. All studies showed high bias in blinding of patients and personnel and blinding of outcome assessment. Other factors in all studies were inclined to indicate an unclear risk of bias (Figure 2). Eight factors were used to assess cohort studies quality according to NOS. Except one study ${ }^{[14]}$ missed one indicator, other studies were adequate in all criteria. The results showed that all observational studies were high quality (Table 2).

\section{Comparison of OSR}

Four $^{[13,18-20]}$, three ${ }^{[13,18,20]}$ and two ${ }^{[16,19]}$ articles which were all cohort studies reported 1-, 2- and 5-year OSR, respectively. Figure 3 revealed a marginal significant difference between patients treated with rh-endostatin combined treatment and chemotherapy only treatment in 1-year and 2-year OSR, but not 5year OSR, using the fixed-effects model, due to a low heterogeneity across all the studies $\left(p=0.42, I^{2}\right.$ $=2 \%$ ). The values of OR for rh-endostatin combined treatment comparing with chemotherapy only treatment were $2.57(95 \% \mathrm{CI}=1.37-4.82, p=0.003)$ for 1-year survival, $2.46(95 \% \mathrm{CI}=1.31-4.65$, $p=0.005)$ for 2-year survival, and $0.79(95 \%$ $\mathrm{CI}=0.33-1.90, p=0.60)$ for 5-year survival. The funnel plot did not show obvious asymmetry. We investigated the influence of single study on the overall pooled estimate by eliminating small sample study in each turn. No significant influence was observed for the results of meta-analysis, which showed the result was stable.

\section{Potentially relevant references searched via database searching (Pubmed $n=54$; Embase $n=159$; Cochrane $n=2$; web of science $n=49$; CNKI $n=177$; WanFang $n=99$ )}

\begin{tabular}{|c|c|}
\hline & $\begin{array}{l}\text { Reference excluded }(\mathrm{n}=540) \\
>\text { Duplicate }(\mathrm{n}=97) \\
>\text { Not relevant }(\mathrm{n}=315) \\
>\text { Not clinical trails }(\mathrm{n}=61)\end{array}$ \\
\hline \multicolumn{2}{|c|}{ Articles retrieved for full text $(n=67)$} \\
\hline & $\begin{array}{l}\text { Reference excluded }(\mathrm{n}=58) \\
>\text { Case reports }(\mathrm{n}=24) \\
>\text { Lacking of control }(\mathrm{n}=4) \\
>\text { Pharmacokinetic study of Endostar }(\mathrm{n}=1) \\
>\text { Not primary study }(\mathrm{n}=25) \\
>\text { Including other sources of tumor }(\mathrm{n}=3) \\
>\text { Other intervention were not the same } \\
\text { between two groups }(\mathrm{n}=1)\end{array}$ \\
\hline
\end{tabular}

Figure 1. Literature search process that identified eligible clinical trials 


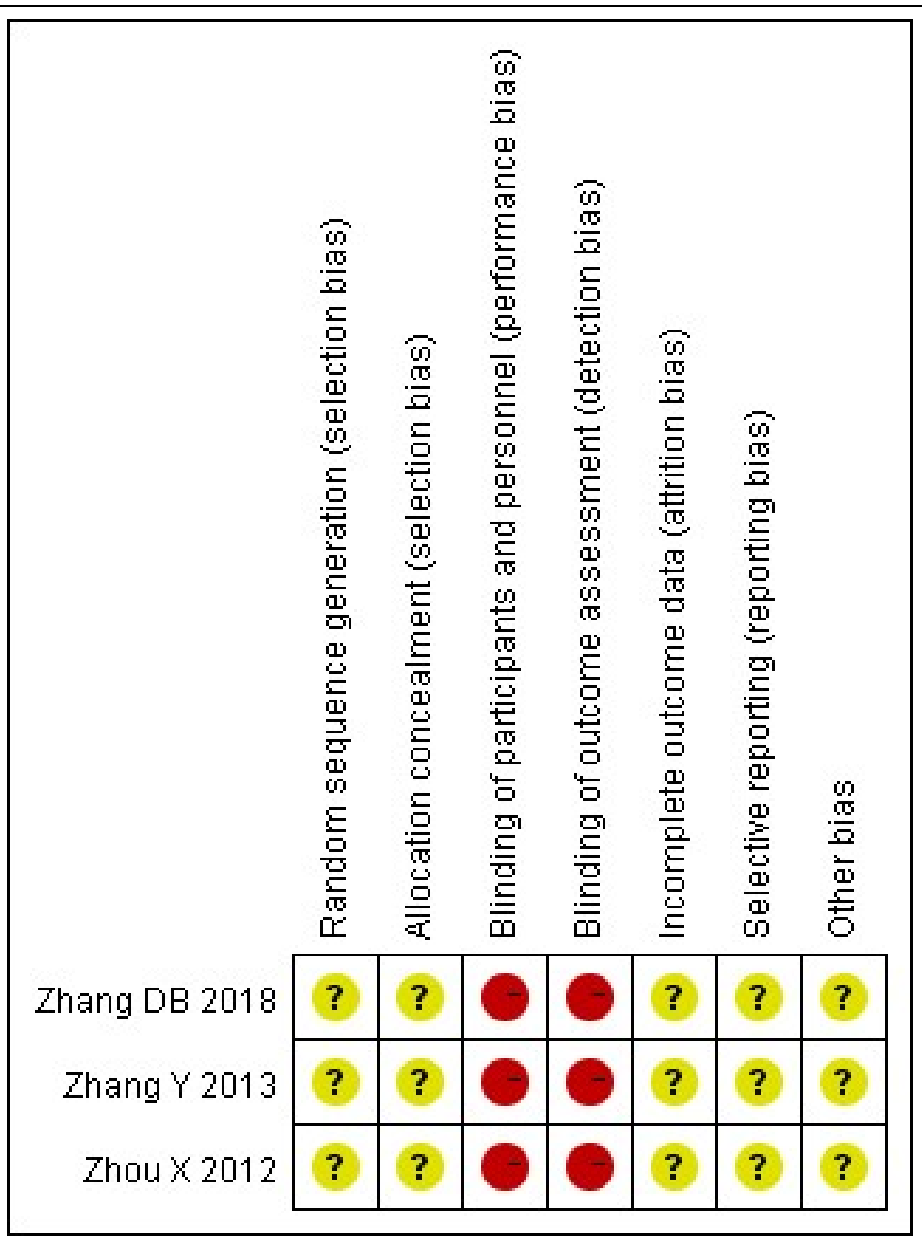

Figure 2. Risk of bias summary review authors' judgements about each risk of bias item for each RCT

Table 2. Quality of observational studies (indicators from New-Castle-Ottawa scale)

\begin{tabular}{|c|c|c|c|c|c|c|c|c|c|c|}
\hline \multirow{2}{*}{\multicolumn{2}{|c|}{ Reference }} & \multicolumn{4}{|c|}{ Selection } & \multicolumn{2}{|c|}{ Comparability } & \multicolumn{2}{|c|}{ Outcomes } & \multirow[t]{2}{*}{ Total } \\
\hline & & $1^{\mathrm{a}}$ & $2^{b}$ & $3^{c}$ & $4^{\mathrm{d}}$ & $5^{e}$ & $6^{\mathrm{f}}$ & $7^{\mathrm{g}}$ & $8^{\mathrm{h}}$ & \\
\hline $\begin{array}{l}\mathrm{Xu} \\
2013\end{array}$ & HR & $*$ & $*$ & $*$ & $*$ & $* *$ & $*$ & $*$ & $*$ & 9 \\
\hline $\begin{array}{l}\text { Yan } \\
2015\end{array}$ & HL & $*$ & $*$ & $*$ & $*$ & $* *$ & $*$ & $*$ & & 8 \\
\hline $\begin{array}{l}\mathrm{Xu} \\
2013\end{array}$ & M & $*$ & $*$ & $*$ & $*$ & $* *$ & $*$ & $*$ & $*$ & 9 \\
\hline $\begin{array}{l}\text { Zhang } \\
2013\end{array}$ & LP & $*$ & $*$ & $*$ & $*$ & $* *$ & $*$ & $*$ & $*$ & 9 \\
\hline $\begin{array}{l}\text { Xing } \\
2017\end{array}$ & PP & $*$ & $*$ & $*$ & $*$ & $* *$ & $*$ & $*$ & $*$ & 9 \\
\hline $\begin{array}{l}\text { Shen } \\
2016\end{array}$ & XJ & $*$ & $*$ & $*$ & $*$ & $* *$ & $*$ & $*$ & $*$ & 9 \\
\hline $\begin{array}{l}{ }^{\mathrm{a}} \text { Repre } \\
{ }^{\mathrm{b}} \text { Selec } \\
{ }^{\mathrm{c}} \text { Ascer } \\
{ }^{\mathrm{d}} \text { Demo } \\
{ }^{\mathrm{e}} \text { Comp } \\
{ }^{\mathrm{f}} \text { Cohor } \\
{ }^{\mathrm{g}} \text { Asses } \\
{ }^{\mathrm{h}} \text { Follo }\end{array}$ & $\begin{array}{l}\text { esent } \\
\text { tion } \\
\text { tainn } \\
\text { onstra } \\
\text { arab } \\
\text { rts co } \\
\text { ssmer } \\
\text { W-up }\end{array}$ & $\begin{array}{l}\text { tive } \\
\text { f the } \\
\text { lent } \\
\text { tion } \\
\text { lity } \\
\text { npar } \\
\text { t of } \\
\text { long }\end{array}$ & $\begin{array}{l}\text { the } \\
\text { expo } \\
\text { oosul } \\
\text { utco } \\
\text { torts } \\
\text { on ot } \\
\text { me } \\
\text { gh f }\end{array}$ & $\begin{array}{l}\text { coh } \\
\text { rt } \\
\text { eres } \\
\text { sis } \\
\text { ors }\end{array}$ & $\begin{array}{l}\text { rese } \\
\text { sn or }\end{array}$ & $\begin{array}{l}\operatorname{tart} \mathrm{C} \\
\text { sis }\end{array}$ & & & & \\
\hline
\end{tabular}




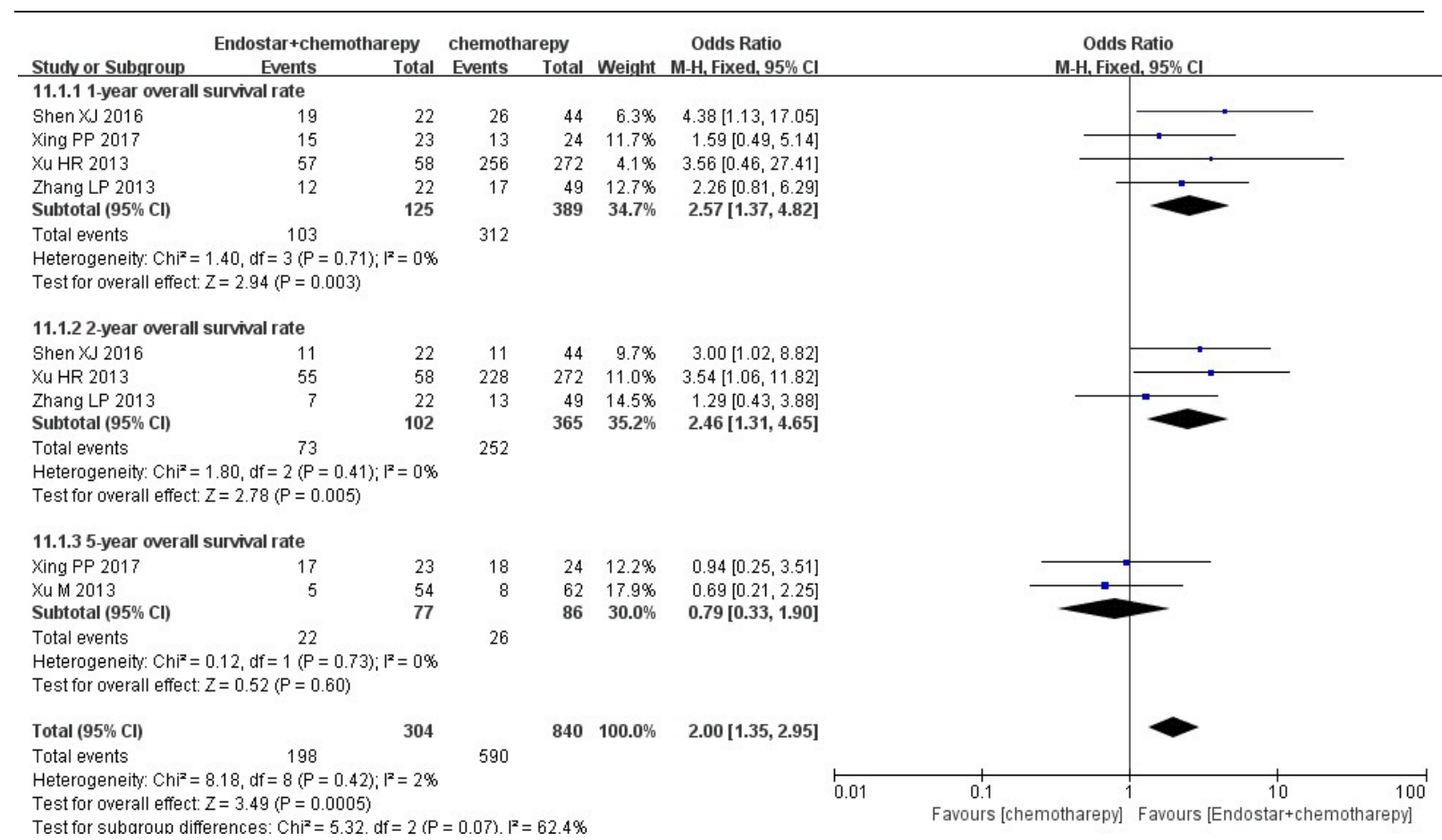

Figure 3. Comparison of overall survival rate between rh-endostatin combined group versus chemotherapeutic agents alone group for treating bone and soft tissue sarcomas

\section{Comparison of ORR}

We identified three RCTs and three cohort studies pertaining to ORR comparison. In the pooled results the OR of fixed-effects was 2.06 (95\% CI=1.15-3.68, $p=0.01$; Figure 4 ), which indicated that the ORR of rh-endostatin combined treatment was significantly higher than that of chemotherapeutic agents alone. Whereas, results were also not significant from RCTs subgroup (OR 2.26, 95\% CI=1.00-5.08, $p=0.05$ ) and cohort studies subgroup (OR 1.85, 95\% $\mathrm{CI}=0.80-4.28, p=0.15)$. This was probably because the sample size was not enough in each subgroup to indicate significant difference. Among these 6 studies, we did not observe the evidence of heterogeneity ( $p=0.73, I^{2}=0 \%$ ). Obvious asymmetry was not found in the funnel plot. But the results of sensitivity analysis showed substantial modification of the estimates after exclusion of the study of Zhang $Y$ et $a^{[15]}$.

\section{Comparison of CBR}

One RCT and two cohort studies were contained. The patients of rh-endostatin combined treatment group indicated higher CBR than chemotherapy alone treatment group (OR 4.58, 95\% CI=1.83-11.43, $p=0.001$; Figure 5). Only one study in RCT subgroup didn't show statistic difference. Significant heterogeneity was not found in the analysis of CBR $\left(p=0.89, \quad I^{2}=0 \%\right)$. Moreover, sensitivity analysis revealed the odds ratio and $95 \% \mathrm{CI}$ did not change when we omitted anyone study. The publication bias was not assessed for the CBR, because only a small number of studies reported this outcome.

\section{Comparison of DCR}

Only two studies reported DCR. In the study of Zhang DB et al ${ }^{[21]}$, in the rh-endostatin group and the control group, DCR were $52.17 \%$ and 23.08 , respectively $(p<0.005)$. And Shen $\mathrm{XJ}$ et $\mathrm{al}^{[20]}$ reported the DCR was $77.3 \%$ and $59.1 \%$ in the rhendostatin group and the control group, respectively, but there was no statistical differences between two groups $(p=0.144)$. Thus, we could not come to a conclusion whether rh-endostatin treatment significantly improved the DCR in patients with soft tissue sarcomas according to current studies.

\section{Comparison of DMR}

A total of three cohort studies were included. The pooled OR for DMR showed a significant difference between the rh-endostatin combined group and the control group (OR 0.48, 95\% CI $=0.27-0.84 . p=0.01$; Figure 6$)$. There was no significant heterogeneity $\left(I^{2}=0 \%\right)$, and the pooled OR for distant metastasis rate was performed using a fixed effects model. Sensitivity analysis showed that the result was reliable after exclusion of small sample study. 


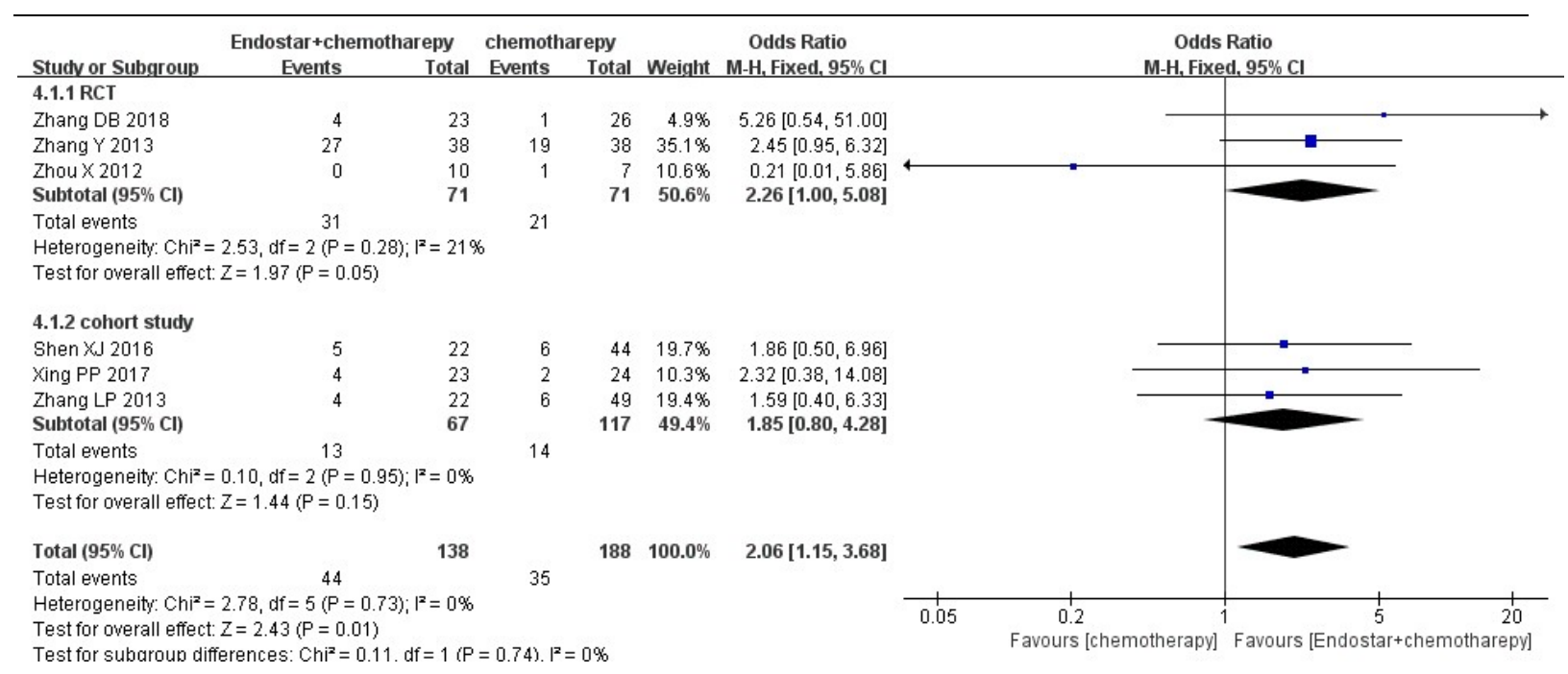

Figure 4. Comparison of objective remission rate between rh-endostatin combined group versus chemotherapeutic agents alone group for treating bone and soft tissue sarcomas

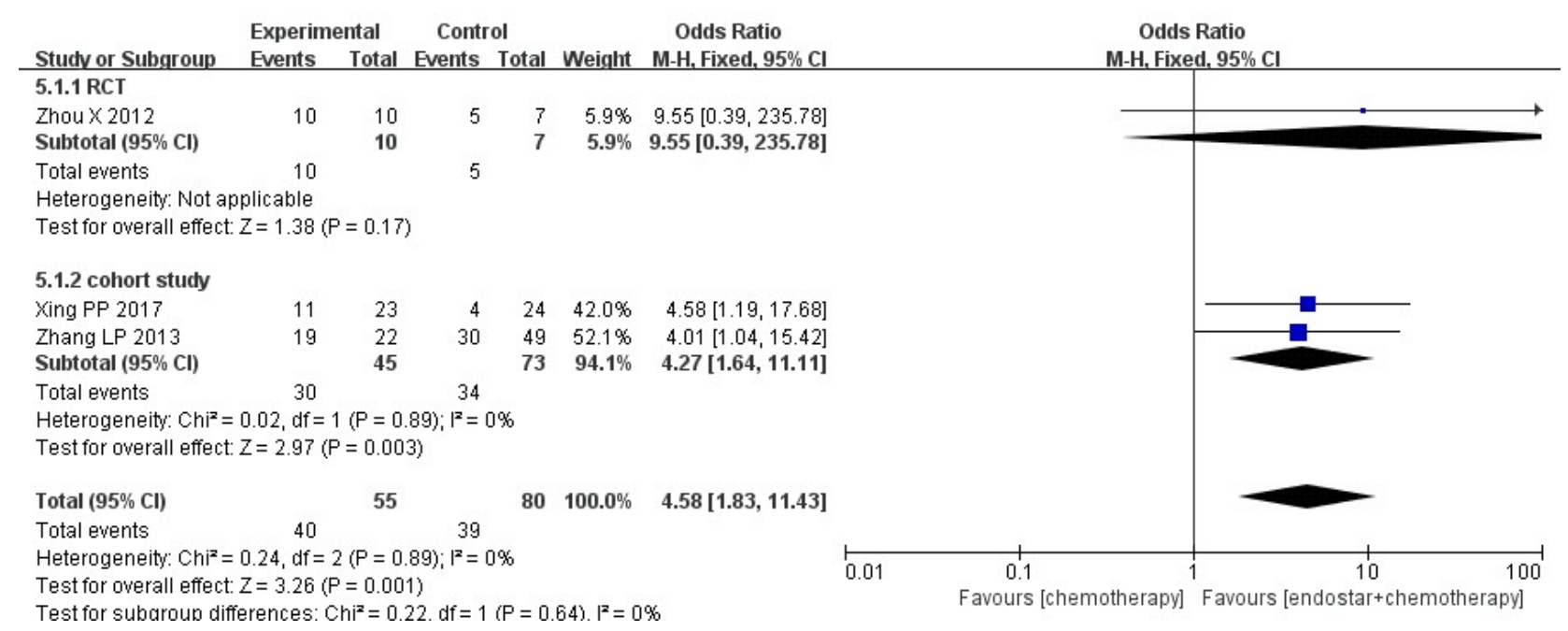

Figure 5. Comparison of clinical benefit rate between rh-endostatin combined group versus chemotherapeutic agents alone group for treating bone and soft tissue sarcomas

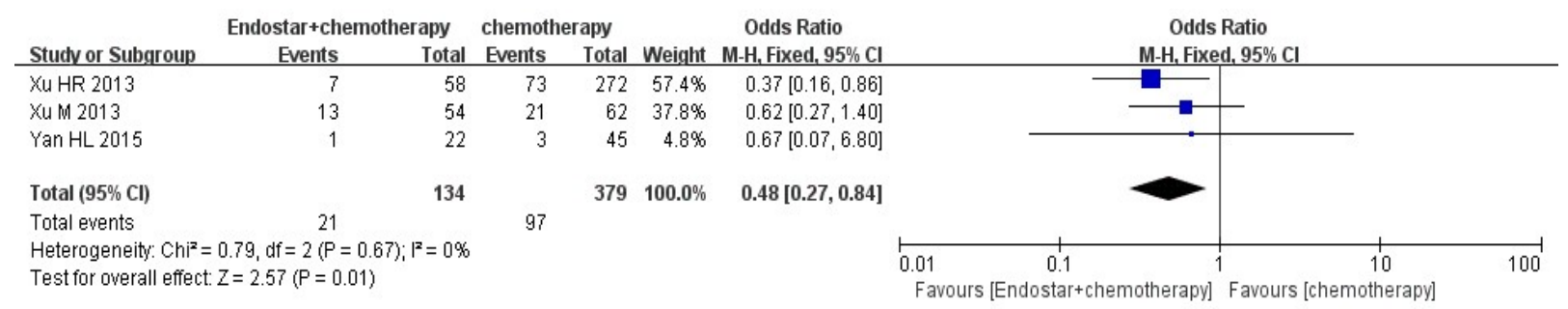

Figure 6. Comparison of distant metastasis rate between rh-endostatin combined group versus chemotherapeutic agents alone group for treating bone and soft tissue sarcomas

\section{Comparison of AEs}

A total of seven articles reported hematologic toxicity. There was no significant difference between the rh-endostatin combined group and the chemotherapeutic agents alone group in hematologic toxicity (OR $0.73,95 \% \quad \mathrm{CI}=0.52-1.03, p=0.07$;
Figure 7). Results from RCTs and cohort studies both indicated no statistical significance (OR 0.76, 95\% $\mathrm{CI}=0.38-1.53, p=0.45$ and $\mathrm{OR} 0.72,95 \%$ $\mathrm{CI}=0.48-1.07, p=0.10$; respectively). The subgroup analysis showed that incidence of leucopenia, thrombocyte decrease, hemoglobin decrease, 
neutrophils decrease, myelosuppression were similar in trial groups and control groups. Two RCTs and three cohort studies reported gastrointestinal toxicity. The meta-analysis showed that incidence of gastrointestinal toxicity in two projects did not have a significant difference (OR 0.62, 95\% CI $=0.19-1.95$, $p=0.41$; Figure 8 ) and the results of RCTs group and cohort studies group were consistent. One RCT and two cohort studies compared cardiotoxicity. The pooled results suggested that the incidence rate of these cardiotoxicity did not have differences between both of two groups (OR 2.43, 95\% CI 0.4313.64, $p=0.31$; Figure 9) and the results of RCTs group and cohort studies group were consistent. All AEs were performed using a fixed effects model due to a low heterogeneity. No significant influence was observed for the results of meta-analysis by eliminating small sample study in each turn.

\section{DISCUSSION}

Tumor growth, invasions, and metastasis, including sarcomas, depend on angiogenesis, which prompts angiogenesis inhibitors as a new approach for tumor treatment ${ }^{[9]}$. Endostatin, isolated from the culture supernatant of a murine hemangioendothelioma, could inhibit the growth of a wide variety of tumors and prevent the progression of pulmonary metastasis ${ }^{[10,11,22]}$. In the past decades, several studies have reported on the efficacy and safety of rhendostatin in the treatment of sarcomas ${ }^{[16,18]}$. This meta-analysis was performed to evaluate the benefits and toxicities of rh-endostatin combined with chemotherapeutic agents versus chemotherapeutic agents alone for treating sarcomas.

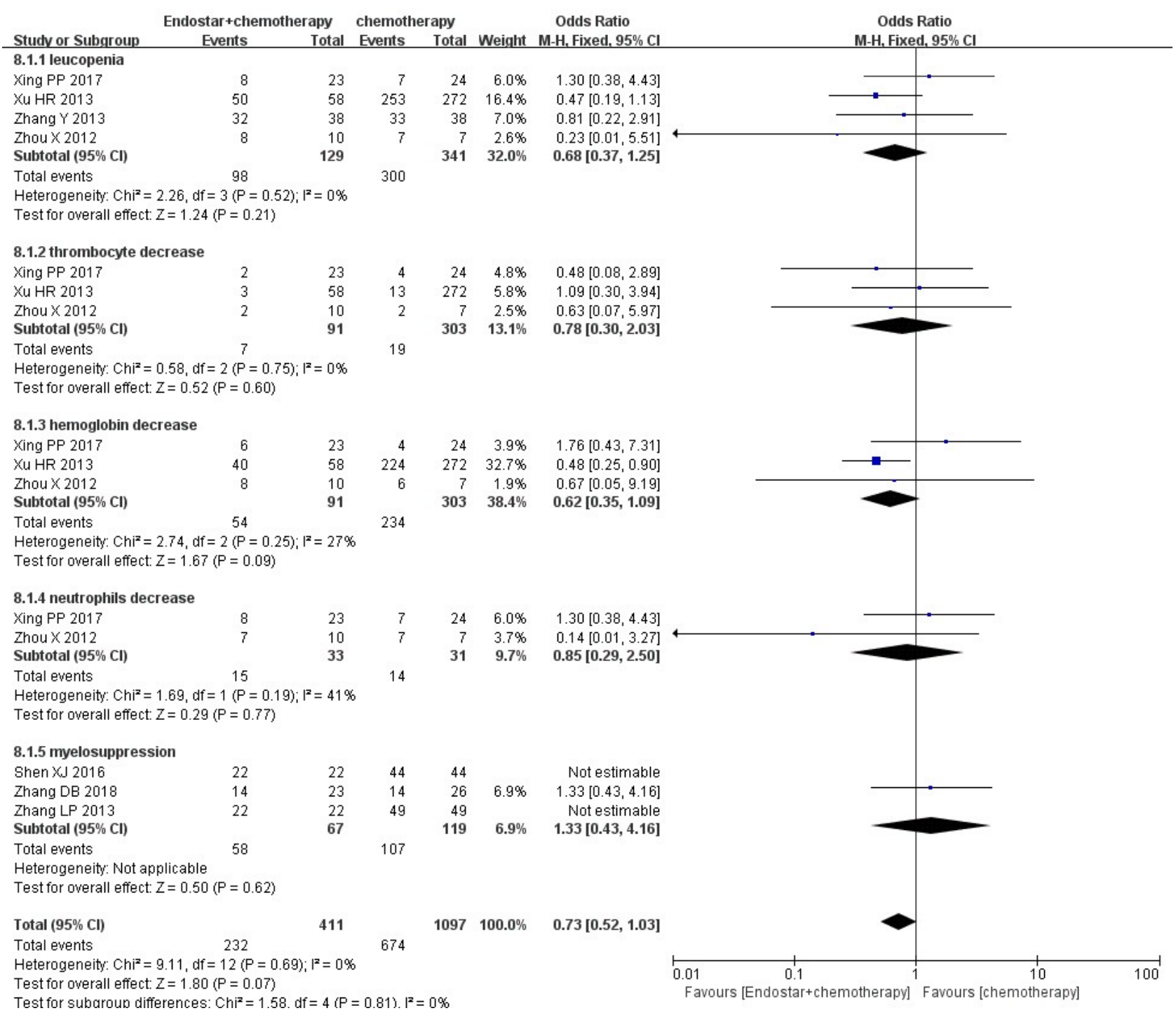

Figure 7. Comparison of hematologic toxicity between rh-endostatin combined group versus chemotherapeutic agents alone group for treating bone and soft tissue sarcomas 


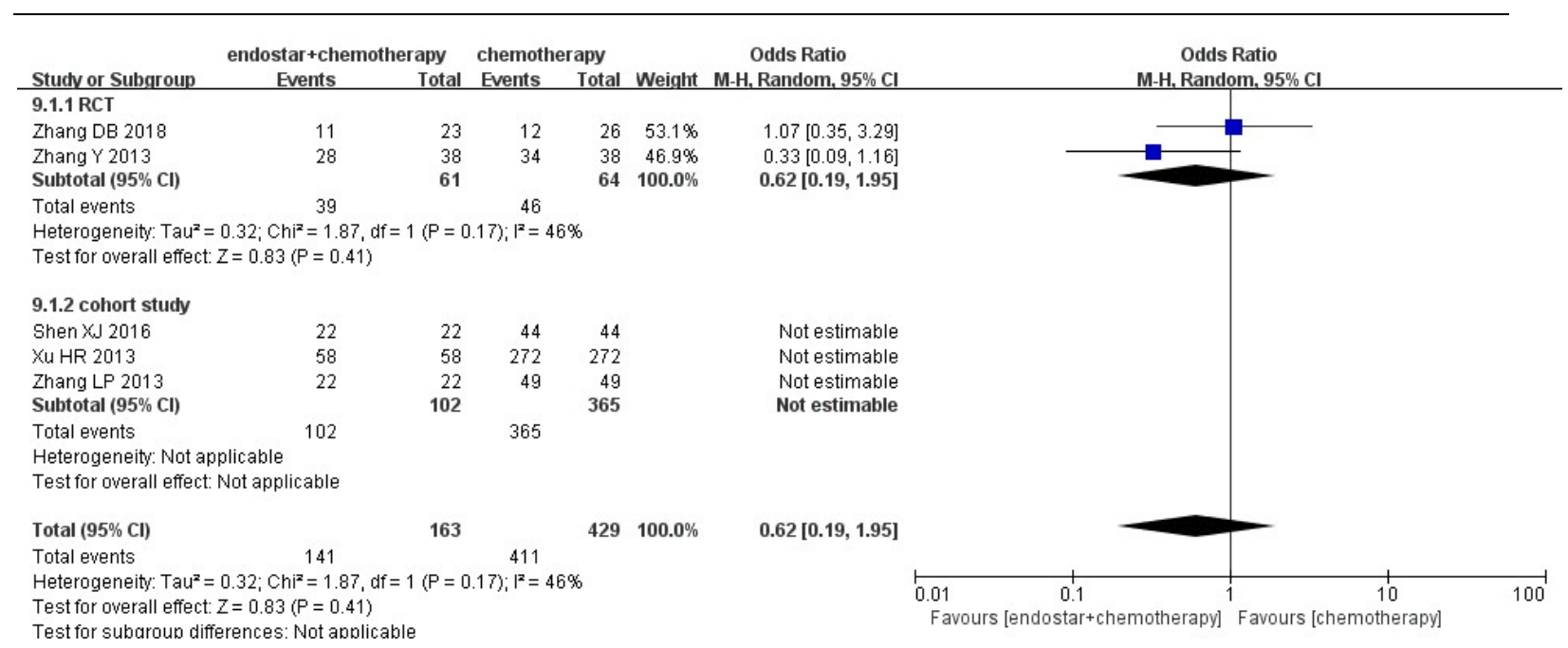

Figure 8. Comparison of gastrointestinal toxicity between rh-endostatin combined group versus chemotherapeutic agents alone group for treating bone and soft tissue sarcomas

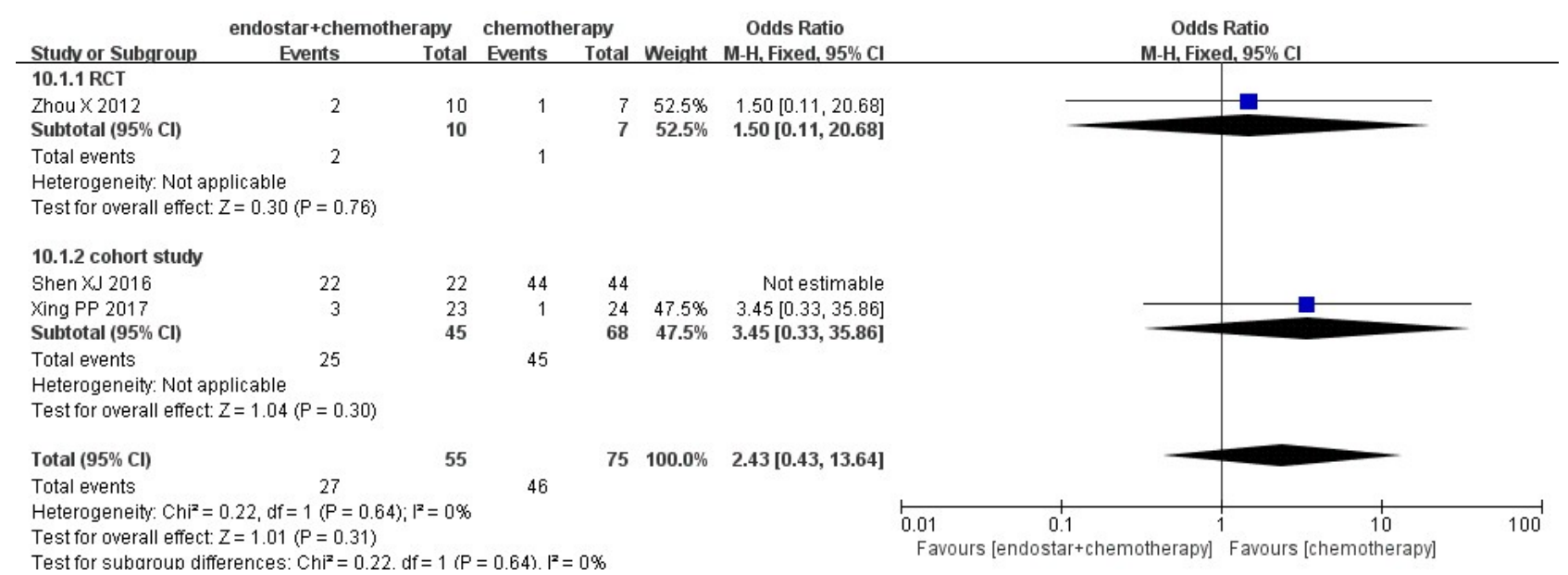

Figure 9. Comparison of cardiotoxicity between rh-endostatin combined group versus chemotherapeutic agents alone group for treating bone and soft tissue sarcomas

Here, for the first time we summed up 9 studies including prospective studies, retrospective studies, and RCTs with 839 patients, and found that rhendostatin combined with chemotherapeutic agents had better 1-year and 2-year OSR, ORR, CBR, and DMR benefits compared with chemotherapeutic agents alone. These results corroborated that combination of rh-endostatin with chemotherapeutic agents exhibited superior efficacy for treating sarcomas compared with chemotherapeutic agents alone. It was reported that cardiotoxicity is one of the common AEs of rh-endostatin ${ }^{[23]}$, we found that the incidence rate of cardiotoxicity did not have differences between two groups. In addition, we noticed that the incidence of hematologic toxicity (leucopenia, thrombocyte decrease, hemoglobin decrease, neutrophils decrease, myelosuppression) and gastrointestinal toxicity in treatment of rhendostatin combination was as high as that in chemotherapeutic agents alone, indicating that the rh-endostatin did not have an extra impact on the incidence of the AEs.

Since heterogeneity might affect the pooled statistical efficacy, addressing statistical heterogeneity is important to meta-analysis. In this analysis, the enrolled studies were carefully determined. A good clinical homogeneity was confirmed, Mantel-Haenszel fixed effects model was used when there was no significant heterogeneity between studies, and publication bias was not found according to the funnel plot analysis. However, this meta-analysis had some limitations. First, the quality of the RCTs was low. Second, the number of trials included in each outcome was too 
small to assess meaningful differences in the outcomes in Egger's test and Begg's test, despite the funnel plot of the outcomes was symmetry. Third, the result of ORR sensitivity analysis showed substantial modification of the estimates after exclusion of the study of Zhang Y et al ${ }^{[15]}$, indicating the result of ORR sensitivity analysis was unstable. Finally, considering rh-endostatin was only approved by CFDA, nearly all the enrolled patients were from China, which may lead to geographical and ethnic bias. Despite several mentioned-above shortcomings, our analysis still proposed a credible suggestion that rh-endostatin combined with chemotherapeutic agents had significant benefits in 1-year and 2-year OSR, ORR, CBR, and DMR compared with chemotherapeutic agents alone. The latest Chinese Society of Clinical Oncology (CSCO) guidelines (Version V1. 2018) recommend rhendostatin plus chemotherapy as first-line treatment options for osteosarcoma in stage IIB/III.

The results for the first time showed that rhendostatin concomitant with chemotherapy exhibited superior efficacy in soft tissue and bone sarcomas treatment compared with chemotherapeutic agents alone after pulling 9 studies with insignificant data. Meanwhile, rhendostatin combined with chemotherapeutic agents did not have an extra impact on the incidence of the AEs. Above all, these results demonstrated rhendostatin could improve the efficacy without increasing side effects for treating soft tissue and bone sarcomas. However, confirmation of these conclusions in rigorously controlled randomized trials is required before firm conclusions about this therapy can be drawn.

\section{REFERENCES}

[1] Rosenberg AE. WHO Classification of Soft Tissue and Bone, fourth edition: summary and commentary. Current opinion in oncology. Sep 2013;25(5):571573.

[2] Burningham Z, Hashibe M, Spector L, Schiffman JD. The epidemiology of sarcoma. Clinical sarcoma research. Oct 4 2012;2(1):14.

[3] Fletcher CD. The evolving classification of soft tissue tumours - an update based on the new 2013 WHO classification. Histopathology. Jan 2014;64(1):2-11.

[4] Kumar S, Marfatia R, Tannenbaum S, Yang C, Avelar E. Doxorubicin-induced cardiomyopathy 17 years after chemotherapy. Texas Heart Institute journal. 2012;39(3):424-427.

[5] Longhi A, Ferrari S, Bacci G, Specchia S. Longterm follow-up of patients with doxorubicininduced cardiac toxicity after chemotherapy for osteosarcoma. Anti-cancer drugs. Jul
2007;18(6):737-744.

[6] Zucali PA, Bertuzzi A, Parra HJ, Campagnoli E, Quagliuolo V, Santoro A. The "old drug" dacarbazine as a second/third line chemotherapy in advanced soft tissue sarcomas. Investigational new drugs. Apr 2008;26(2):175-181.

[7] Hensley ML, Maki R, Venkatraman E, et al. Gemcitabine and docetaxel in patients with unresectable leiomyosarcoma: results of a phase II trial. Journal of clinical oncology : official journal of the American Society of Clinical Oncology. Jun 15 2002;20(12):2824-2831.

[8] Judson I, Verweij J, Gelderblom H, et al. Doxorubicin alone versus intensified doxorubicin plus ifosfamide for first-line treatment of advanced or metastatic soft-tissue sarcoma: a randomised controlled phase 3 trial. The Lancet. Oncology. Apr 2014;15(4):415-423.

[9] Folkman J. Antiangiogenesis in cancer therapy-endostatin and its mechanisms of action. Experimental cell research. Mar 10 2006;312(5):594-607.

[10] Guo L, Song N, He T, et al. Endostatin inhibits the tumorigenesis of hemangioendothelioma via downregulation of CXCL1. Molecular carcinogenesis. Nov 2015;54(11):1340-1353.

[11] Fu Y, Tang H, Huang Y, Song N, Luo Y. Unraveling the mysteries of endostatin. IUBMB life. Jun 2009;61(6):613-626.

[12] Biaoxue R, Xiguang C, Hua L, Wenlong G, Shuanying Y. Thoracic perfusion of recombinant human endostatin ( $\mathrm{Rh}$-endostatin) combined with chemotherapeutic agents versus chemotherapeutic agents alone for treating malignant pleural effusions: a systematic evaluation and meta-analysis. $B M C$ cancer. Nov 14 2016;16(1):888.

[13] Xu HR, Li B, Huang Z, Zhang Q,Niu XB. A controlled non-randomized clinical research on chemotherapy combined with rh-endostatin for stage IIBostosarcoma. Chinese Clinical Oncology. May2013;18(5):421-425.

[14] Yan HL, Zhang ZC, Yang QC, Qin S, Dong Y. A Prospective Non-randomized Controlled Clinical Trial on Rh-endostatinCombined with Chemotherapy for Treatment of Patient withOsteosarcoma. Progress in Modern Biomedicine. Sep2015;15(25):4866-4871.

[15] Zhang Y, Ren LF. Clinical Analysis of the Recombinant Human Endostatin Combined with DIAin the Treatment of Osteosarcoma. Anti-tumor Pharmacy.Oct2013;3(5):368-371.

[16] Xu M, Xu CX, Bi WZ, et al. Effects of rh-endostatin combined multidrug chemotherapy in osteosarcoma. Bone. Nov 2013;57(1):111-115.

[17] Zhou X, Shi X, Wu SJ, et al.A clinical observation of rh-endostatin ( rh-endostatin) combined with chemotherapy for osteosarcoma. J Med Postgra. Jan2012;25(1):39-42.

[18] Zhang LP, Liao XY, Xu YM, et al. Efficacy and safety of rh-endostatin(R) combined with 
chemotherapy in patients with advanced soft tissue sarcomas. Asian Pacific journal of cancer prevention : APJCP. 2013;14(7):4255-4259.

[19] Xing PP, Zhang J, Yan Z, et al. Recombined humanized endostatin (Rh-endostatin) combined with chemotherapy for advanced bone and soft tissue sarcomas in stage IV. Oncotarget. May 2017;8(22):36716-36727.

[20] Shen XJ, Cao S.Efficacy and safety of chemotherapy combined with recombinant human endostatin in patients with metastatic soft tissue sarcomas. Chin J Prev Treat. Oct 2016;23(19):13131317.

[21] Zhang DB, Kang YX, Guo YZ. Efficacy and safety of rh-endostatin combined with gemcitabine and docetaxel in advanced soft tissue sarcomas. Modern Oncology. Jan 2018;26(5):769-772.

[22] Chen J, Yao Q, Li D, et al. Neoadjuvant rhendostatin, docetaxel and epirubicin for breast cancer: efficacy and safety in a prospective, randomized, phase II study. BMC cancer. May 21 2013;13:248.

[23] Guo L, Geng X, Chen Y, et al. Pre-clinical toxicokinetics and safety study of M2ES, a PEGylated recombinant human endostatin, in rhesus monkeys. Regulatory toxicology and pharmacology: RTP. Aug 2014;69(3):512-523. 
J Pharm Pharm Sci (www.cspsCanada.org) 21, 386 - 397, 2018

Table 1. Characteristics of the eligible studies

\begin{tabular}{|c|c|c|c|c|c|c|c|c|c|c|}
\hline \multirow{2}{*}{ Studies } & \multirow{2}{*}{ Study design } & \multirow{2}{*}{$\begin{array}{c}\text { Sources } \\
\text { of tumor }\end{array}$} & \multirow{2}{*}{ Grade } & \multirow{2}{*}{ Sample/n } & \multirow{2}{*}{$\mathrm{F} / \mathrm{M}$} & \multirow{2}{*}{ Age } & \multicolumn{2}{|c|}{ Intervations } & \multirow{2}{*}{$\begin{array}{c}\text { Treatment } \\
\text { cycle }\end{array}$} & \multirow{2}{*}{ Outcome } \\
\hline & & & & & & & Trial group & Control group & & \\
\hline $\begin{array}{l}\text { Xu HR } \\
2013\end{array}$ & $\begin{array}{l}\text { Prospective } \\
\text { cohort study }\end{array}$ & $\begin{array}{l}\text { bone } \\
\text { sarcomas }\end{array}$ & IIB & $58 / 272$ & $114 / 216$ & $6-65$ & $\begin{array}{l}\text { Rh-endostatin } \\
15 \mathrm{mg} \mathrm{d} 1-\mathrm{d} 14+ \\
\text { chemotherapy }\end{array}$ & $\begin{array}{l}\text { methotrexate } 10 \mathrm{~g} / \mathrm{m}^{2} \mathrm{~d} 1, \\
\text { ifosfamide } 3 \mathrm{~g} / \mathrm{m}^{2} \mathrm{~d} 1-\mathrm{d} 5, \\
\text { cisplatin } 120 \mathrm{mg} / \mathrm{m}^{2} \mathrm{~d} 1, \\
\begin{array}{l}\text { doxorubicin } \quad 30 \mathrm{mg} / \mathrm{m}^{2} \\
\mathrm{~d} 1-\mathrm{d} 3\end{array}\end{array}$ & $\begin{array}{l}21 \mathrm{~d} / \text { cycle } \\
4 \text { cycles }\end{array}$ & (1) (2) 79 \\
\hline $\begin{array}{l}\text { Yan HL } \\
2015\end{array}$ & $\begin{array}{l}\text { Prospective } \\
\text { cohort study }\end{array}$ & $\begin{array}{l}\text { bone } \\
\text { sarcomas }\end{array}$ & II & $22 / 45$ & $23 / 44$ & $6-65$ & $\begin{array}{l}\text { Rh-endostatin } \\
15 \mathrm{mg} \text { iv } \mathrm{d} 1-\mathrm{d} 5 \\
\text { or d1-d10 + } \\
\text { chemotherapy }\end{array}$ & $\begin{array}{l}\text { doxorubicin } 30 \mathrm{mg} / \mathrm{m}^{2} \\
\mathrm{~d} 1-\mathrm{d} 3, \text { cisplatin } 120 \\
\mathrm{mg} / \mathrm{m}^{2} \mathrm{~d} 4, \text { methotrexate } \\
10-12 \mathrm{~g} / \mathrm{m}^{2} \mathrm{~d} 1 \text {, ifosfamide } \\
3 \mathrm{~g} / \mathrm{m}^{2} \mathrm{~d} 1-\mathrm{d} 5\end{array}$ & 2 cycles & (7) \\
\hline $\begin{array}{l}\text { Zhang } \\
\text { Y } 2013\end{array}$ & $\mathrm{RCT}$ & $\begin{array}{l}\text { bone } \\
\text { sarcomas }\end{array}$ & $\begin{array}{l}\text { IIA、IIB、 } \\
\text { III }\end{array}$ & $38 / 38$ & $32 / 44$ & $\begin{array}{l}\text { T: } \\
24.4 \pm 1.7 \\
\text { C: } \\
25.1 \pm 2.6\end{array}$ & $\begin{array}{l}\text { Rh-endostatin } \\
15 \mathrm{mg} \text { iv d1-d14 } \\
+ \text { chemotherapy }\end{array}$ & $\begin{array}{l}\text { cisplatin } 120 \mathrm{mg} / \mathrm{m}^{2} \mathrm{~d} 1 \text {, } \\
\text { ifosfamide } 2 \mathrm{~g} / \mathrm{m}^{2} \mathrm{~d} 7-\mathrm{d} 12, \\
\begin{array}{l}\text { doxorubicin } \\
\text { d7 }-\mathrm{d} 10\end{array}\end{array}$ & 2 cycles & (4) (8) (9) \\
\hline $\begin{array}{l}\mathrm{Xu} \quad \mathrm{M} \\
2013\end{array}$ & $\begin{array}{l}\text { Prospective } \\
\text { cohort study }\end{array}$ & $\begin{array}{l}\text { bone } \\
\text { sarcomas }\end{array}$ & IIA、IIB & $54 / 62$ & $46 / 70$ & $3-40$ & $\begin{array}{l}\text { Rh-endostatin } \\
15 \mathrm{mg} \mathrm{d} 1-\mathrm{d} 14+ \\
\text { chemotherapy }\end{array}$ & $\begin{array}{l}\text { doxorubicin } 60 \mathrm{mg} / \mathrm{m}^{2} \text {, } \\
\text { cisplatin } 120 \mathrm{mg} / \mathrm{m}^{2} \text {, } \\
\text { methotrexate } 12 \mathrm{~g} / \mathrm{m}^{2}\end{array}$ & 4 cycles & (3) 7 \\
\hline $\begin{array}{l}\text { Zhou X } \\
2012\end{array}$ & $\mathrm{RCT}$ & $\begin{array}{l}\text { bone } \\
\text { sarcomas }\end{array}$ & $\begin{array}{l}\text { Not } \\
\text { mentioned }\end{array}$ & $10 / 7$ & $9 / 8$ & $10-60$ & $\begin{array}{l}\text { Rh-endostatin } \\
7.5 \mathrm{mg} / \mathrm{m}^{2} \mathrm{~d} 1- \\
\mathrm{d} 14, \mathrm{~d} 35-\mathrm{d} 49+ \\
\text { chemotherapy }\end{array}$ & $\begin{array}{lr}\text { methotrexate } & 10 \mathrm{~g} / \mathrm{m}^{2} \mathrm{~d} 1, \\
\text { cisplatin } & 100-120 \mathrm{mg} / \mathrm{m}^{2} \\
\mathrm{~d} 21-\mathrm{d} 22, & \text { doxorubicin } \\
60 \mathrm{mg} / \mathrm{m}^{2} & \mathrm{~d} 21-\mathrm{d} 22, \\
\text { ifosfamide } & 3 \mathrm{~g} / \mathrm{m}^{2} \mathrm{~d} 35-\mathrm{d} 40\end{array}$ & 4 cycles & (4) (5) (8) 10 \\
\hline $\begin{array}{l}\text { Zhang } \\
\text { LP } \\
2013\end{array}$ & $\begin{array}{l}\text { Retrospective } \\
\text { cohort study }\end{array}$ & $\begin{array}{l}\text { soft tissue } \\
\text { sarcomas }\end{array}$ & IIB、III 、IV & $22 / 49$ & $26 / 45$ & $18-70$ & $\begin{array}{l}\text { Rh-endostatin } \\
15 \text { mg iv d1- } \\
\text { d14, d2 } 1-\mathrm{d} 28+ \\
\text { chemotherapy }\end{array}$ & $\begin{array}{lr}\text { mainly } & \text { docetaxel, } \\
\text { gemcitabine, } & \\
\text { doxorubicin, } & \\
\text { ifosfamide, } & \text { cisplatin, } \\
\text { vincristine } & \text { and } \\
\text { temozolomide } & \end{array}$ & $\begin{array}{l}\text { Not } \\
\text { mentioned }\end{array}$ & (1) (2) (4) (5) (9) \\
\hline $\begin{array}{l}\text { Xing } \\
\text { PP } \\
2017 \\
\end{array}$ & $\begin{array}{l}\text { Retrospective } \\
\text { cohort study }\end{array}$ & $\begin{array}{l}\text { bone and } \\
\text { soft tissue } \\
\text { sarcomas }\end{array}$ & IV & $23 / 24$ & $16 / 31$ & $12-70$ & $\begin{array}{l}\text { Rh-endostatin } \\
15 \mathrm{mg} \text { iv d1-d14 } \\
+ \text { chemotherapy }\end{array}$ & $\begin{array}{l}\text { mainly ifosfamide } 8-12 \\
\mathrm{~g} / \mathrm{m}^{2}, \quad \text { doxorubicine } \\
75 \mathrm{mg} / \mathrm{m}^{2}, \text { methotrexate } 8-\end{array}$ & $21 \mathrm{~d} /$ cycle & (1) (4) (5) (10) \\
\hline
\end{tabular}




\begin{tabular}{|c|c|c|c|c|c|c|c|c|c|c|}
\hline $\begin{array}{l}\text { Shen } \\
\text { XJ } \\
2016\end{array}$ & $\begin{array}{l}\text { Retrospective } \\
\text { cohort study }\end{array}$ & $\begin{array}{l}\text { soft tissue } \\
\text { sarcomas }\end{array}$ & IV & $22 / 44$ & $33 / 33$ & $18-69$ & $\begin{array}{l}\text { Rh-endostatin } \\
15 \mathrm{mg} \text { iv d1-d } 14 \\
+ \text { chemotherapy }\end{array}$ & $\begin{array}{l}12 \mathrm{~g} / \mathrm{m}^{2}, \text { cisplatin } 80- \\
120 \mathrm{mg} / \mathrm{m}^{2}, \text { dacarbazine } \\
200-400 \mathrm{mg} / \mathrm{m}^{2}, \\
\text { gemcitabine } 1000 \mathrm{mg} / \mathrm{m}^{2}, \\
\text { docetaxel } 75 \mathrm{mg} / \mathrm{m}^{2} \\
\text { doxorubicine, ifosfamide, } \\
\text { dacarbazine, gemcitabine, } \\
\text { docetaxel }\end{array}$ & $21 \mathrm{~d} /$ cycle & (1)(2)(4)(6) (9)(10) \\
\hline $\begin{array}{l}\text { Zhang } \\
\text { DB } \\
2018 \\
\end{array}$ & $\mathrm{RCT}$ & $\begin{array}{l}\text { soft tissue } \\
\text { sarcomas }\end{array}$ & $\begin{array}{l}\text { Not } \\
\text { mentioned }\end{array}$ & $23 / 26$ & $21 / 28$ & $23-67$ & $\begin{array}{l}\text { Rh-endostatin } \\
30 \mathrm{mg} \text { iv d1-d } 7+ \\
\text { chemotherapy }\end{array}$ & $\begin{array}{l}\text { gemcitabine } \quad 900 \mathrm{mg} / \mathrm{m}^{2} \text {, } \\
\text { docetaxel } 75 \mathrm{mg} / \mathrm{m}^{2},\end{array}$ & $\begin{array}{l}21 \mathrm{~d} / \text { cycle } \\
2 \text { cycles }\end{array}$ & (4) (6) (9) \\
\hline
\end{tabular}

Abbreviations: RCT, randomized controlled trial; d, day; T, trial group; C, control group

Note: (1)1-year overall survival rate; (2)2-year overall survival rate; (3)5-year overall survival rate; (4)objective remission rate; (5)clinical benefit rate; (6)disease control rate; (7)distant metastasis rate; (8)hematologic toxicity; (9)gastrointestinal toxicity; (10)cardiotoxicity. 
J Pharm Pharm Sci (www.cspsCanada.org) 21, 386 - 397, 2018 